\title{
Profile and scientific production of the Brazilian Council for Scientific and Technological Development (CNPq) researchers in the field of Hematology/Oncology
}

\author{
Maria Christina lopes Araujo Oliveira ${ }^{1 *}$, Daniella Reis Martelli², Isabel Gomes Quirino ${ }^{3}$, Enrico Antônio Colosimo4, \\ Ana Cristina Simões e Silva ${ }^{5}$, Hercílıo Martelli Júnior ${ }^{6}$, Eduardo Araujo de Oliveira ${ }^{5 *}$ \\ ${ }^{1}$ Associate Professor, Faculty of Medicine of the Federal University of Minas Gerais (UFMG), Belo Horizonte, MG, Brazil \\ ${ }^{2}$ Adjunct Professor, State University of Montes Claros, Montes Claros, MG, Brazil \\ ${ }^{3}$ Professor, University of José do Rosário Vellano (Unifenas), Alfenas, MG, Brazil \\ ${ }^{4}$ Full Professor, Statistics Department UFMG, Belo Horizonte, MG, Brazil \\ ${ }^{5}$ Full Professor, Faculty of Medicine UFMG, Belo Horizonte, MG, Brazil \\ ${ }^{6}$ Full Professor, Unimontes, Montes Claros, MG, Brazil
}

Study conducted by the Federal University of Minas Gerais and State University of Montes Claros, MG

Article received: $4 / 11 / 2014$ Accepted for publication: 4/12/2014

*Correspondence: Address: Rua Engenheiro Amaro Lanar 389 apt 501 Postal Code: $30310-580$ Belo Horizonte, MG eduolive812@gmail.com

Financial Support: FAPEMIG http://dx.doi.org/10.1590/1806-9282.60.06.012 Conflict of interest: none

\section{SUMMARY}

Objective: several studies have examined the academic production of the researchers at the CNPq, in several areas of knowledge. The aim of this study was to evaluate the scientific production of researchers in Hematology/Oncology who hold scientific productivity grants from the Brazilian Council for Scientific and Technological Development.

Methods: the Academic CVs of 28 researchers in Hematology/Oncology with active grants in the three-year period from 2006 to 2008 were included in the analysis. The variables of interest were: institution, researchers' time after doctorate, tutoring of undergraduate students, masters and $\mathrm{PhD}$ degree, scientific production and its impact. Results: from a total of 411 researchers in Medicine, 28 (7\%) were identified as being in the area of Hematology/Oncology. There was a slight predominance of males (53.6\%) and grant holders in category 1 . Three Brazilian states are responsible for approximately $90 \%$ of the researchers: São Paulo (21,75\%), Rio de Janeiro (3,11\%), and Minas Gerais $(2,7 \%)$. During their academic careers, the researchers published 2,655 articles, with a median of 87 articles per researcher ( $\mathrm{IQR}=52$ to 122 ). 65 and $78 \%$ of this total were indexed on the Web of Science and Scopus databases, respectively. The researchers received 14,247 citations on the WoS database with a median of 385 citations per researcher. The average number of citations per article was 8.2.

Conclusion: in this investigation, it was noted that researchers in the field of $\mathrm{He}-$ matology/Oncology have a relevant scientific output from the point of view of quantity and quality compared to other medical specialties.

Keywords: scientific publication indicators, hematology, oncology, postgraduate programs in health, health sciences.

\section{INTRODUCTION}

In recent years a significant increase in Brazilian scientific production has been noted, demonstrated by the growing number of articles published in indexed periodicals concomitant with the formation of new researchers. ${ }^{1}$ Scientific publications by Brazilian researchers in indexed periodicals jumped from 14,237 in 2003 to 30,415 in 2008, according to data from Thomson Reuters. ${ }^{2}$ Recent estimates have also shown that this production has been consistent and has improved from a qualitative point of view. ${ }^{3,4}$ Data from January to October 2012 published by Nature, for example, show that Brazilian researchers have published 29,924 articles. ${ }^{5}$ Furthermore, in 2012, $0.43 \%$ of the Brazilian scientific production was placed at the top of the most cited articles. Interestingly, the 
country was ranked third in terms of growth in this criterion, with an $8.9 \%$ increase in articles placed among the top $1 \%$ most cited articles. ${ }^{5}$

In a recent analysis, we showed that among grant holders with scientific production at the CNPq in the area of medicine, the field of Hematology/Oncology corresponds to $7 \%$ of researchers. ${ }^{6}$ In an extensive comparative analysis of scientific production in three major areas, Rodrigues et al. ${ }^{7}$ showed that Oncology is a field with a growing trend to consolidate itself as an important area in science and technology in Brazil. However, systematic analyses by researchers in the area of Hematology/Oncology remain scarce.

Several studies have examined the academic production of the researchers at the $\mathrm{CNPq}$, in several areas of knowledge. ${ }^{8-12}$ This cross-sectional study has the objective of describing the demographic characteristics and academic production of researchers holding grants in Medicine from the $\mathrm{CNPq}$, and whose main area of work is Hematology/Oncology.

\section{Methods}

\section{Participants}

A database of 411 researches registered as grant holders with scientific production at the CNPq was initially established, according to the list provided by this federal agency for research funding in February 2009. ${ }^{6}$

\section{Field of activity}

The area specifically indicated by the researcher in his/her Academic (Lattes) CV was considered for this variable. Whenever this information was not given, the scientific production over the last five years was analyzed and an area was attributed according to the predominant topics published and/or directed. According to this methodology, we identified 28 researchers working in the field of Hematology/Oncology.

\section{Study design cross-sectional study}

\section{Data collection protocol}

After identifying grant holders, the Academic CVs were systematically consulted, as published on the Lattes platform (CNPq). The Academic CVs were used to build a database with information relating to the distribution of grants by category $(1 \mathrm{~A}, 1 \mathrm{~B}, 1 \mathrm{C}, 1 \mathrm{D}$ and category 2$),{ }^{13}$ geographic and institution distribution, researchers' time after doctorate, scientific production (scientific articles) and guidance of human resources (supervision of undergraduates, masters and doctorates). To analyze scientific production, all publications and supervision during the researcher's career and the last five years of the period under study were included.

\section{Variables of interest}

The following variables were analyzed: gender, the researcher's institution, researchers' time after doctorate, doctoral institution, grant category, supervision for undergraduate researchers (BIC), master's thesis and doctoral dissertation, and publications in journals. In relation to supervision and publications, the absolute values of the entire scientific career were evaluated, as well as the values relating to the period from 2004 to 2008. Furthermore, the supervision and publications adjusted by the researchers' time after doctorate were calculated. We also searched the Web of Science (WoS)- Institute for Scientific Information (apps.isiknowledge.com/) and Scopus (www.scopus.com/home.url) databases. Both were consulted via the CAPES website (novo.periodicos.capes.gov.br). These databases were used to search the scientific articles published by the researchers listed on the CNPq database. The scientific name of the researcher used in this investigation was that provided in their Academic $\mathrm{CV}$, but there was an extensive search of possible variations in researcher names. The performance indicators of the researchers were also included in the analysis, such as the number of citations, the $\mathrm{H}$-index and the M-index. ${ }^{1418}$

\section{Statistical analysis}

The development of a database and the statistical analyses were conducted using the Statistical Package for Social Sciences (SPSS) software, version 18.0 for Windows. For the statistical analysis, regarding the grant holder categories, researchers were stratified into three groups: levels $1 \mathrm{~A}$ and $1 \mathrm{~B}$, levels $1 \mathrm{C}$ and $1 \mathrm{D}$ and level 2 . The continuous data were reported using median and interquartile range (IQRR). The non-parametric Mann-Whitney test was used for comparison between categories of researchers. Dichotomous variables or nominal variables were compared using the Chi-squared test. A significance level of $5 \%$ was used.

\section{Results}

From a total of 411 researchers in Medicine, 28 (7\%) were identified as being in the area of Hematology/Oncology. The distribution of the 28 researchers by gender and grant category are summarized in Table 1 . There was a slight predominance of males (53.6\%) and grant holders in category $1(53.6 \%)$. There was no significant difference in the distribution of categories between genders $(p=0.24)$. Three Brazilian states are responsible for approximately 90\% of the researchers: São Paulo (21,75\%), Rio de Janeiro $(3,11 \%)$, and Minas Gerais (2, $7 \%)$. In relation to the institution of origin, the researchers are distributed among nine different institutions in the country. However, three institutions are responsible for approximately $70 \%$ of 
the researchers: USP $(8,28.6 \%)$, Unicamp $(8,28.6 \%)$, and Unifesp (4, 14.3\%). Three researchers (10.7\%) reported pediatrics as their field of work.

The median doctoral time of the 28 researchers was 16 years (IQRR, 13 - 24.5 years). In relation to the doctoral institution, 25 researchers obtained their title in Brazil and three at institutions abroad (England and Germany). Three institutions are responsible for training approximately $80 \%$ of the researchers: USP $(9,32 \%)$, Unifesp (6, 21\%), and Unicamp (5, 18\%), and UFRGS $(3,9 \%)$. Nineteen researchers $(68 \%)$ have a post-doctorate, with institutions in the United States (7) and United Kingdom (4) predominating.

TABLE 1 Distribution of grant-holding researchers in the field of Hematology/Oncology according to gender and CNPq categorization $(n=28)$

\begin{tabular}{l|l|l|l}
\hline Grant category & Male & Female & Total $(\%)$ \\
\hline $1 \mathrm{~A}$ & 3 & 2 & $5(17.8)$ \\
\hline $1 \mathrm{~B}$ & 2 & 1 & $3(10.7)$ \\
\hline $1 \mathrm{C}$ & 4 & 0 & $4(14.3)$ \\
\hline $1 \mathrm{D}$ & 1 & 2 & $3(10.7)$ \\
\hline 2 & 5 & 8 & $13(46.4)$ \\
\hline Total & 15 & 13 & $28(100)$ \\
\hline
\end{tabular}

\section{Academic supervision}

Overall in their academic careers, these Hematology/Oncology researchers supervised 213 undergraduate grant holders (BIC), with a median of $2(\mathrm{IQRR}=0.0$ to 10.0$)$ per researcher, with 293 master's theses (median 10, IQRR $=5.0$ - 16) and 188 doctoral dissertations (median 5, IQRR $=3$ 10). The median supervision per year in relation to the values adjusted for doctoral time were 0.18 for BIC, 0.47 for master's degree students and 0.32 for doctoral students. Comparing the values adjusted by doctoral time there was no significant difference between the categories of grant holders in terms of student supervision for BIC students $(\mathrm{p}=0.58)$, master's students $(\mathrm{p}=0.25)$, and doctoral students $(\mathrm{p}=0.24)$.

\section{Scientific production}

During their academic careers, researchers published 2,655 articles in journals, with a median of 87 articles per researcher $(I Q R R=52$ - 122), ranging from a minimum of 19 articles to a maximum of 220 . In total, there were 1,719 articles indexed by the WoS database, approximately $65 \%$ of the total number of articles published (median of 50 per researcher, $\mathrm{IQRR}=35$ - 71). On the Scopus database there were 2,075 articles indexed (median of 69, IQRR 4162 ), equivalent to $78 \%$ of the academic production.

Considering the number of articles adjusted by time after doctorate, the median of publications was 4.4 articles/year (IQRR $=3.6$ to 5.7). The adjusted median for articles published on the WoS database was 2.7/year (IQRR $=2.2$ to 3.7) and 3.4/year $(\mathrm{IQRR}=2.5$ to 4.6$)$ on the Scopus database. Comparing the values adjusted by time after doctorate there was no significant difference between the categories of grant holders and the number of articles throughout their careers $(\mathrm{p}=0.26)$, articles indexed by the $\operatorname{WoS}(\mathrm{p}=0.13)$ and articles indexed by Scopus database $(\mathrm{p}=0.35)$.

All 28 researchers increased scientific production over the last five years analyzed, considering the average number of articles published per year. This increase ranged from 8 to $243 \%$, with a median increase of $85 \%$ (IQRR $39-106 \%$ ) in scientific production. The average number of articles published in the scientific career of the 28 researchers was 4.7 years $(\mathrm{SD}=3.2)$ while over the last five years this average reached 7 per year $(\mathrm{SD}=3.8)$. Figure 1 illustrates the annual average articles published in the entire scientific career of the 28 researchers, and their average over the past five years.

\section{Impact of the scientific production}

In their academic careers, researchers in Hematology/ Oncology received a total of 14,247 citations in WoS database, with a median of 385 citations per researcher $($ IQRR $=208-741$, ranging $68-1897$ citations). The average number of citations per article was $8.2(\mathrm{SD}=3.6)$. There was a significant difference between the categories when comparing the absolute number of citations received by the researchers. The median citations for researchers in categories $1 \mathrm{~A} / 1 \mathrm{~B}$ was $701(\mathrm{IQRR}=518$ $1195)$, while for categories $1 \mathrm{C} / 1 \mathrm{D}$ this was $324(\mathrm{IQRR}=$ $117-547)$ and 255 for category $2(\mathrm{IQRR}=166-483)(\mathrm{p}$ $=0.011)$. When assessing the groups, the difference occurred among $1 \mathrm{~A} / 1 \mathrm{~B}$ groups compared to the $1 \mathrm{C} / 1 \mathrm{D}$ and category 2 groups. However, there was no difference in the comparison between $1 \mathrm{C} / 1 \mathrm{D}$ and category 2 groups (Figure 2). This significant difference persisted even after adjustment for the researchers' time after doctorate. The average for researchers in categories $1 \mathrm{~A}$ and $1 \mathrm{~B}$ were 39 citations/year $(\mathrm{SD}=19.4)$, while for categories $1 \mathrm{C}-1 \mathrm{D}$ this was 19 citations year $(\mathrm{SD}=11)$ and 24 citations/year $(\mathrm{SD}=13.9)$ for category $2(\mathrm{P}=0.04)$. 


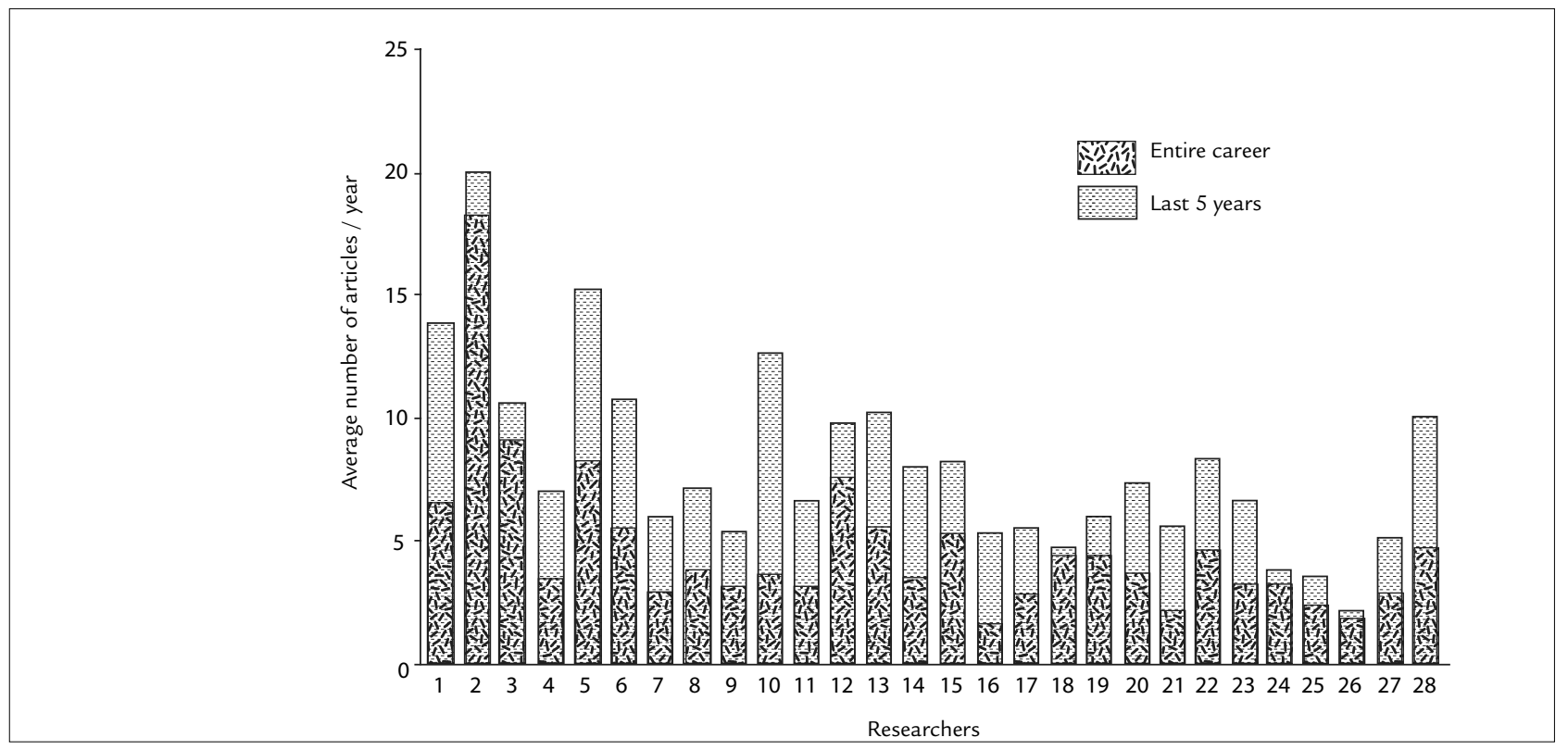

FIGURE 1 Articles published by CNPq researchers with expertise in the area of Hematology-Oncology, comparing all academic careers within the period of 2004-2008.

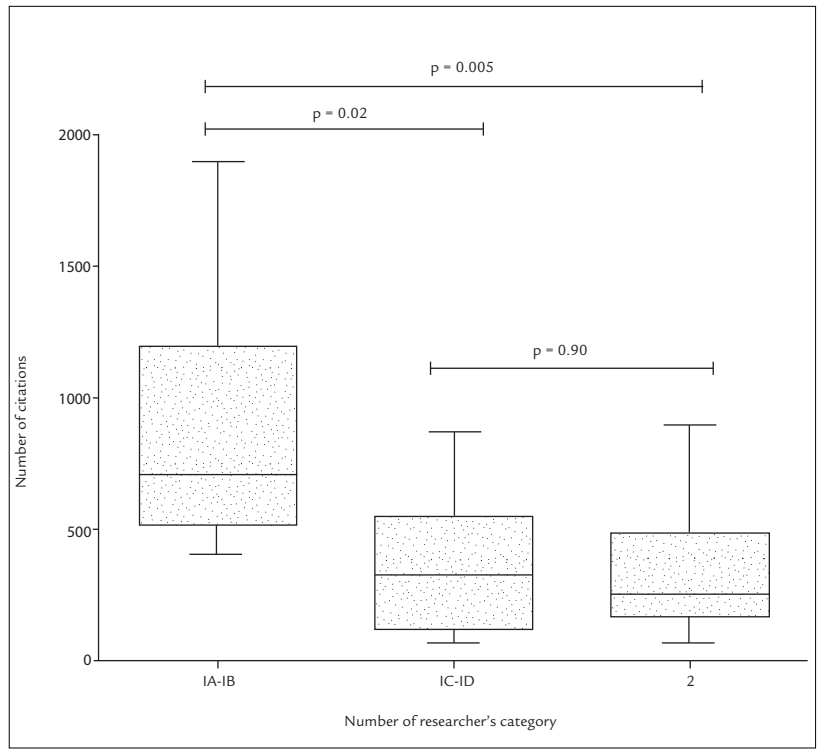

FIGURE 2 Comparison of the number of citations received with the category of CNPq researchers operating in the area of Hematology-Oncology.

The median H-index on the WoS database was 11 (IQRR 7.2 - 13) ranging from a minimum of 4 to a maximum of 20. There was a significant difference in the median of the H-index according to the researcher's grant category on the WoS database $(\mathrm{P}=0.005)$. The median $\mathrm{H}$-index for researchers in categories $1 \mathrm{~A}$ and $1 \mathrm{~B}$ was $14(\mathrm{IQRR}=12.2$ to 16.8$)$, while for categories $1 \mathrm{C}-1 \mathrm{D}$ this was $8(\mathrm{IQRR}=$ $5-12)$ and 9 for category $2(\mathrm{IQRR}=6.5$ to 11.5$)$. The median $\mathrm{M}$-index, i.e. the $\mathrm{H}$-index corrected by the time of the researcher's academic career, was 0.55 on the WoS database (IQRR $=0.39$ to 0.72 ), ranging from a minimum of 0.29 up to a maximum of 1.3. However, there was no significant difference for the $\mathrm{M}$-index between grant-holder categories on the WoS database $(\mathrm{P}=0.38)$. The median $\mathrm{M}$-index for researchers in categories $1 \mathrm{~A}$ and $\mathrm{IB}$ was 0.58 (IQRR $=0.44$ to 0.99 ), while for categories $1 \mathrm{C}-1 \mathrm{D}$ this was $0.41(\mathrm{IQRR}=0.35$ to 0.61$)$ and 0.62 for category 2 (IQRR $=0.42$ to 0.62 ).

\section{Discussion}

Based on the criteria for granting funding for research productivity, including training of new researchers and publications in indexed journals, it can be inferred that this sample is representative of researchers from the academic elite in their respective fields of knowledge. Thus, this cross-sectional study, focusing on CNPq researchers in the field of Hematology/Oncology has shown that there are still few high productivity institutions dealing with research involving these areas of clinical knowledge. The results of this study show a high concentration of scientific production in a few states in the country, especially the states of São Paulo and Rio de Janeiro. 
CNPq researchers in the field of Hematology/Oncology presented an average increase of approximately $85 \%$ in scientific production over the last five years compared to the entire academic career. This fact was also noted in other areas of Health Sciences, such as Dentistry, Public Health and Physiotherapy ${ }^{8,9,11,12}$ as well as other fields of Clinical Medicine. ${ }^{19,20}$ This increase relates to the current positive cycle of Brazilian scientific production and possibly reflects several factors, such as the increase in the federal budget for science and technology, and the various incentive mechanisms established by numerous development agencies in the country. ${ }^{4,21-23}$ For example, the federal budget for science and technology, although still relatively low when compared to developed countries, rose from 1.26 to $1.43 \%$ of the Brazilian gross domestic product in $2008.4,23$

The analysis of Hematology/Oncology researchers showed a significant number of articles published in indexed journals. During their academic careers, the median was 87 articles per researcher, identical to the median of 87 articles of the 411 researchers in the area of Medicine described in a previous study. ${ }^{6}$ However, Hematology/Oncology researchers stand out in qualitative terms, as approximately 65 and $78 \%$ of all published articles were indexed by the WoS and Scopus databases, respectively. It should be noted that these qualitative data are far superior when compared to the general analysis in the scope of Medicine. In our previous analysis it was shown that only 51 and $68 \%$ of the total number of articles published by the 411 researchers were indexed by the WoS and Scopus, respectively. ${ }^{6}$ The data related to researchers in the fields of Cardiology and Newborn's, for example, are also superior, with 55 and $58 \%$ of articles indexed by the WoS database, respectively. ${ }^{19,20}$ This scenario certainly reflects a scientific production with international relevance, since the indexing of journals by these databases has been considered an important parameter for the quality of scientific production.

Despite the scathing criticism of the use of journal impact factor in the evaluation of institutions and researchers, unfortunately this index continues to be adopted by many research funding agencies, including the CNPq. ${ }^{15,17,2429}$ However, considering the current literature on scientific production rates, in our view, the individual assessment of the researchers' careers should be performed using proper indicators developed for this purpose. Among the various indicators for assessing the performance of researchers, the specialized literature has highlighted the $\mathrm{H}$-index, proposed by Hirsch. ${ }^{16}$ The H-index consists of a single number that seeks to summarize two dimensions of academic performance: productivity (number of publications) and visibility (citations for those publications). ${ }^{18,30,31}$ One point that has been emphasized about the H-index is that it counteracts both the excessive amount of publications with few citations as well as low productivity with many citations. ${ }^{32}$ In our analysis, the median $\mathrm{H}$-index for researchers in the field of Hematology/Oncology was 11 , which was significantly higher for categories $1 \mathrm{~A}$ and IB, with an $\mathrm{H}$-index of 14 . The median $\mathrm{H}$-index for researchers in the field of Hematology/Oncology was similar to that previously observed in the areas of Cardiology and $\mathrm{Ne}$ phrology, with respective medians of 11 and $10 .{ }^{19,20}$

One of the disadvantages of the H-index, however, is that it favors researchers with long careers and provides an incomplete picture of actual citations from a determined group of researchers. ${ }^{26}$ Therefore, we understand that the H-index is most valuable if associated with the M-index, which takes into account the researchers' engagement time with their academic career. In this context, it should be noted that unlike the H-index, there was no significant difference for the M-index among the Hematology/Oncology grant holder categories, reinforcing the bias of this indicator proposed by Hirsch in 2005. ${ }^{16}$ In our study, the median M-index in the WoS database was 0.55 , ranging from a minimum of 0.29 to a maximum of 1.3 . The median for the M-index was slightly lower than the median of 0.62 previously described for total of 411 researchers in Clinical Medicine. ${ }^{13}$

\section{Conclusion}

In this study, it was noted that $\mathrm{CNPq}$ researchers in the field of Hematology/Oncology have a relevant scientific output from the point of view of quantity and quality, superior in several criteria compared to that presented by other medical specialties.

\section{ACKNOWLEDGMENTS}

This study was partially funded by the FAPEMIG (Minas Gerais State Research Foundation) through the PPM-0034511 and PPM-00273-13 projects. Eduardo A. Oliveira, Ana Cristina Simões and Silva are CNPq category 2 researchers in the area of Medicine. Hercílio Martelli-Júnior and Enrico A. Colosimo are CNPq category 2 researchers in the areas of Dentistry and Statistics, respectively.

\section{Resumo}

Perfil e produção científica dos pesquisadores do Conselho Nacional de Desenvolvimento Científico e Tecnológico na área de Hematologia-Oncologia.

Objetivo: vários estudos têm analisado a produção acadêmica dos pesquisadores do Conselho Nacional de De- 
senvolvimento Científico e Tecnológico (CNPq), em diversas áreas do conhecimento. O objetivo deste estudo foi avaliar a produção científica de pesquisadores de Hematologia-Oncologia, cadastrados como bolsistas de produtividade científica do CNPq.

Métodos: os currículos Lattes de 28 pesquisadores em Hematologia-Oncologia, com bolsas ativas no triênio 2006 a 2008, foram incluídos na análise. As variáveis de interesse foram: instituição, tempo de doutoramento, orientação de alunos de graduação, mestres e doutores, artigos publicados e seu impacto.

Resultados: de um total de 411 pesquisadores em Medicina, 28 (7\%) foram identificados como da área da Hematologia-Oncologia. Houve uma discreta predominância do gênero masculino $(53,6 \%)$ e de bolsistas na categoria 1 (53,6\%). Três Estados da Federação são responsáveis por 90\% dos pesquisadores: São Paulo (21; 75\%), Rio de Janeiro $(3 ; 11 \%)$ e Minas Gerais $(2 ; 7 \%)$. No total da carreira acadêmica, os pesquisadores publicaram 2.655 artigos em periódicos, sendo a mediana de 87 artigos por pesquisador (intervalo interquartil [IQ] $=52-122$ ). Desse total, $65 \%$ e 78\% foram artigos indexados nas bases de dados Web of Science (WoS) e Scopus, respectivamente. Os pesquisadores receberam 14.247 citações na base de dados WoS, sendo a mediana por pesquisador de 385 citações. A média de citações por artigo foi de 8,2.

Conclusão: na presente investigação, observou-se que os pesquisadores na área de Hematologia-Oncologia apresentam uma produção científica relevante do ponto de vista qualitativo quando comparada a das demais especialidades médicas.

Palavras-chave: indicadores de produção científica; hematologia; oncologia; programas de pós-graduação em saúde; ciências da saúde.

\section{References}

1. Zorzetto R, Razzouk D, Dubugras MT, Gerolin J, Schor N, Guimarães JA, et al. The scientific production in health and biological sciences of the top 20 Brazilian universities. Braz J Med Biol Res. 2006;39:1513-20.

2. Petherick A. High hopes for Brazilian science. Nature. 2010;465:674-5

3. Regalado A. Science in Brazil. Talented but underfunded: Brazils future scientists. Science. 2010;330:1311.

4. Regalado A. Science in Brazil. Brazilian science: riding a gusher. Science. 2010;330:1306-12

5. Van Noorden R. 366 days: the year in science. Nature. 2013;492:324-7.
6. Martelli-Junior H, Martelli DR, Quirino IG, Oliveira MC, Lima LS, Oliveira EA. [CNPq researchers in medicine: a comparative study of research areas] Rev Assoc Med Bras. 2010;56:478-83.

7. Rodrigues PS, Fonseca L, Chaimovich H. Mapping cancer, cardiovascular and malaria research in Brazil. Braz J Med Biol Res. 2000;33:853-67.

8. Barata RB, Goldbaum M. [A profile of researchers in public health with productivity grants from the Brazilian National Research Council (CNPq)]. Cad Saúde Pública. 2003;19:1863-76.

9. Cavalcante RA, Barbosa DR, Bonan PRF, Pires MBO, Martelli-Junior H. Perfil dos pesquisadores da área de odontologia no Conselho Nacional de Desenvolvimento Científico e Tecnológico (CNPq). Rev Bras Epidemiol. 2008;11:106-13.

10. Mendes PHC, Martelli DR, Souza WP, Filho SQ, Martelli Junior H. Perfil dos pesquisadores bolsistas de produtividade científica na medicina no CNPq, Brasil. Rev Bras Educ Med. 2010;34:535-45.

11. Santos NCF, Candido LFO, Kuppens CL. Produtividade em pesquisa do CNPq: análise do perfil dos pesquisadores da química. Quim Nova 2010;33:489-95.

12. Santos SMC, Lima LS, Martelli DR, Martelli Junior H. Perfil dos pesquisadores da Saúde Coletiva no Conselho Nacional de Desenvolvimento Científico e Tecnológico. Physis. 2009;19:761-75

13. Oliveira EA, Colosimo EA, Martelli DR, Quirino IG, Oliveira MCL, Lima LS, et al. Comparison of Brazilian researchers in clinical medicine: are criteria for ranking well-adjusted? Scientometrics. 2012;90:429-43.

14. Bornmann L, Mutz R, Daniel H-D. Are there better indices for evaluation purposes than the $\mathrm{h}$ index? A comparison of nine different variants of the $\mathrm{h}$ index using data from biomedicine. J Am Soc Inform Sci Technol. 2008;59:830-7

15. Haeffner-Cavaillon N, Graillot-Gak C. The use of bibliometric indicators to help peer-review assessment. Arch Immunol Ther Exp (Warsz). 2009;57:33-8.

16. Hirsch JE. An index to quantify an individuals scientific research output. Proc Natl Acad Sci USA. 2005;102:16569-72

17. Lehmann $\mathrm{S}$, Jackson $\mathrm{AD}$, Lautrup BE. Measures for measures. Nature. 2006;444:1003-4

18. Panaretos J, Malesios C. Assessing scientific research performance and impact with single indices. Scientometrics. 2009;81:635-70

19. Oliveira EA, Pecoits-Filho R, Quirino IG, Oliveira MC, Martelli DR, Lima LS, et al. Perfil e produção científica dos pesquisadores do CNPq nas áreas de Nefrologia e Urologia. J Bras Nefrol. 2011;33:31-7.

20. Oliveira EA, Ribeiro ALP, Quirino IG, Oliveira MCL, Martelli DR, Lima LS, et al. Perfil e produção científica dos pesquisadores do Conselho Nacional de Desenvolvimento Científico e Tecnológico na área de Cardiologia. Arq Bras Cardiol. 2011;97:186-93.

21. Deheinzelin D, Caramelli B. [Scientific production, post-graduate education and Revista da Associacao Medica Brasileira]. Rev Assoc Med Bras. 2007;53:471-2.

22. Guimaraes R. Challenges of postgraduate human health programs in Brazil. Rev Saúde Pública. 2011;45:1-12,1-3.

23. Regalado A. Science in Brazil. Tapping a deep, pre-salt bounty. Science. 2010;330:1308-9.

24. Bordons M, Fernandez MT, Gomes I. Advantages and limitations in the use of impact factor measures for the assessment of research performance in a peripheral country. Scientometrics. 2002;53:195-206.

25. Brink AJ. Impact factor: use and abuse. Cardiovasc J South Afr. 2004;03:05 PM-7.

26. Moed HF. New developments in the use of citation analysis in research evaluation. Arch Immunol Ther Exp (Warsz). 2009;57:13-8.

27. Simons K. The misused impact factor. Science. 2008;322:165

28. Szklo M. Impact factor: good reasons for concern. Epidemiology. 2008;19:369

29. Wilcox AJ. Rise and fall of the Thomson impact factor. Epidemiology. 2008;19:373-4

30. Burrell QL. Hirsch index or Hirsch rate? Some thoughts arising from Liang's data. Scientometrics. 2007;73:19-28

31. Burrell QL. Hirsch's h-index: a stochastic model. J Informetrics. 2007;01:16 AM-25

32. Boell SK, Wilson CS. Journal Impact Factors for evaluating scientific performance: use of H-like indicators. Scientometrics. 2010;82:613-26. 